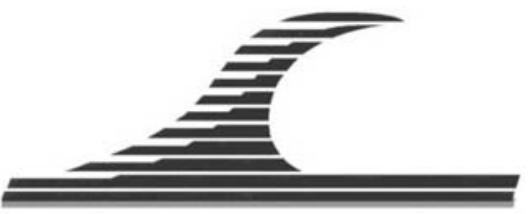

\title{
Is phytoextraction a suitable green treatment for metal-contaminated sediments?
}

\author{
Stéphanie HUGUET ${ }^{1,2,3,4}$, Géraldine SARRET ${ }^{1^{*}}$, Valérie BERT ${ }^{4 *}$, \\ Marie-Pierre ISAURE ${ }^{1}$, Olivier PROUX ${ }^{5}$, Anne-Marie FLANK ${ }^{6,7}$, \\ Vasilica HAMMADE ${ }^{8}$, David BULTEEL ${ }^{2,3}$, Agnès LABOUDIGUE ${ }^{2,3}$
}

1. LGIT : Géochimie de l’Environnement, Université de Grenoble et CNRS, BP 53, 38041 Grenoble Cedex 9, France.

stephanie.huguet@obs.ujf-grenoble.fr,geraldine.sarret@ujf-grenoble.fr

2. Université Lille Nord de France, 59000 Lille, France.

3. EMDouai, MPE-GCE, 930 Boulevard Lahure 59500, Douai, France.

4. INERIS : Unité Déchets et Sites Pollués, Parc technologique Alata, 60550 Verneuil-en-Halatte, France.valerie.bert@ineris.fr

5. Beamline FAME, ESRF, BP220, 38043 Grenoble, France.

6. Beamline LUCIA, SLS, Swiss Light Source, CH-5232 Villigen, Switzerland.

7. Synchrotron SOLEIL, F-91192 Gif Sur Yvette, France.

8. ISSEP, Rue de la Platinerie, 12/Z, 7340, Colfontaine Belgique.

* Equal participation

\begin{abstract}
:
The cleaning of waterways by regular dredging generates great volumes of sediments and, owing to human activities, these sediments often contain large amounts of metals. For some of these contaminated sediments, a treatment by phytoextraction could be considered. To our knowledge, phytoextraction with hyperaccumulating plants has been rarely tested on heavily contaminated sediments. This work consisted in a preliminary study of Cd phytoextraction potentialities and focused on the fate of Cd present in a metal-polluted dredged sediment during the culture of Arabidopsis halleri, a Zn and Cd hyperaccumulating plant. In this purpose, a five month pot experiment was achieved; results obtained for the first four months of monitoring are presented here. Cd contents in the sediment, in the aerial parts of plant and in the leachates were measured each month. Cd speciation in the sediment was studied by EXAFS and $\mu$ XANES spectroscopy, Cd localization by SEM-EDX and $\mu$ XRF. Before culture, Cd was present as mixed $\mathrm{Zn}$, Cd and Fe sulphide in the sediment.
\end{abstract}

Received 2 February 2009, accepted 28 June 2009, available online 18 October 2010. The reviewing procedure concerns the version written in English. The version written in any other language is published under the sole responsibility of the author(s).

UNE VERSION TRADUITE EN FRANCAIS EST DIPONIBLE EN LIGNE

How to cite this paper:

HUGUET S., SARRET G., BERT V., ISAURE M.-P., PROUX O., FLANK A.-M., HAMMADE V., BULTEEL D., LABOUDIGUE A. (2010). Is phytoextraction a suitable green treatment for metal contaminated sediments? Revue Paralia, Vol. 3, pp 4.1-4.14. 
During growth, plants were able to develop on sediment and accumulated about $100 \mathrm{mg}$ $\mathrm{Cd} \mathrm{kg}^{-1}$ in their aerial part from the first month of growth. The presence of plants decreased the amount of leached $\mathrm{Cd}$. First results showed that culture of A. halleri on metal-contaminated sediments met some of the key objectives of Cd phytoextraction.

\section{Introduction}

In the Northern part of France, the maintenance of waterways by regular dredging generates large volumes of metal-polluted sediments, which are often rich in metal contaminants and present a risk to the local environment. These materials are usually deposited on landfill sites (around 180 sites in the Nord-Pas de Calais region). The use of metal hyperaccumulating higher plants to extract metals accumulated in polluted soils (phytoextraction) might represent an alternative low cost remediation strategy (CUNNINGHAM et al., 1995; RASKIN \& ENSLEY, 2000). However, to our knowledge, there are few investigations on phytoextraction using hyperaccumulating plants on contaminated sediments (SEUNTJENS et al., 2002; GIRONDELOT et al., 2003; BERT et al., 2003; HUGUET et al., 2007a).

Plants called hyperaccumulators are defined by their ability to accumulate very high amount of metals in their aerial parts: more than 100, 1000 and $10000 \mathrm{mg} \mathrm{kg}^{-1}$ dry weight (DW) for Cd, Ni and Zn, respectively (BAKER \& BROOKS, 1989). Second to these definitions, A. halleri is considered as a hyperaccumulator, and, as a consequence, might be used in phytoextraction. Previous studies have shown that metal tolerance and accumulation traits vary as a function of the plant origin (LOMBI et al., 2000; BERT et al., 2002). In recent years, Arabidopsis halleri has been intensively studied for the genetics and physiology of metal tolerance and hyperaccumulation (KUPPER et al., 2000; ZHAO et al., 2000; ZHAO et al., 2006; SARRET et al., 2002; BERT et al., 2003; CHO et al., 2003; BECHER et al., 2004; WEBER et al., 2004). Moreover, this species develops populations on contaminated and uncontaminated soil (BERT et al., 2002, 2003). Despite these numerous studies, the mechanisms of cadmium accumulation in plants are still poorly understood and never been studied on strongly contaminated sediment. Besides, data concerning plant impact on Cd remaining in the substrate are lacking. Metal uptake by plants is often limited by low metal bioavailability in soil (McGRATH et al., 2006). This parameter is mostly controlled by the $\mathrm{pH}$ and the composition of the soil (organic and amorphous oxides content, etc...), (COREY et al., 1987; HAE-NAM HYUN et al., 1998; JING \& LOGAN, 1992).

In this study, a 5-month pot experiment was conducted on a $\mathrm{Zn}$ - and Cd-contaminated dredged sediment with A. halleri of two origins, metallicolous and non-metallicolous. The sediment in its initial state was characterized and particularly the chemical form(s) of cadmium was determined using Scanning Electron Microscopy / Energy Dispersive Spectroscopy (SEM-EDS), micro X-Ray Fluorescence ( $\mu \mathrm{XRF}$ ) and, X-ray Absorption Fine Structure (XAFS) spectroscopy. Because Cd concentration is generally very low in 
Is phytoextraction a suitable green treatment for metal contaminated sediments?: 4.3

the sediment, the sensitivity and micrometric resolution of synchrotron techniques are appropriate tools to identify and quantify $\mathrm{Cd}$ chemical species in heterogeneous systems. The knowledge of Cd speciation in freshly dredged sediment and in the same sediment just before plant transfer and after growth at microscopic level was interesting to assess potential Cd mobility. During the culture, plant growth parameters and metal accumulation were monitored. Metal concentrations and $\mathrm{pH}$ in the substrate and leachates as well as metal phytoavailability were also determined. These parameters were predetermining to the comprehension of phytoextraction mechanisms, necessary step toward the application of phytoextraction.

\section{Materials and methods}

\subsection{Origin of the sediment}

The sampling area is located in the North of France, about $30 \mathrm{~km}$ south of Lille. This region is among the oldest and largest industrial areas in Europe. Past and present contaminations by non-ferrous metal processing have released huge amounts of ore particles and slag into the environment (THIRY et al., 2002). Five hundred kilograms of sediment were collected by dredging the Scarpe River at Lallaing lock, downstream from Godion (Scarpe tributary - Fig. 1) in an area known to be heavily polluted with Cd (around $150 \mathrm{mg} \mathrm{kg}^{-1}$ - ALARY, 2001). The sediment was mixed and stored for draining under cover for seven months in order to reduce its water content. Thereafter, the sediment was mechanically homogenized several times. Macroscopic characteristics of the sediment including granulometry, physico-chemical parameters and major and trace element concentrations were determined.

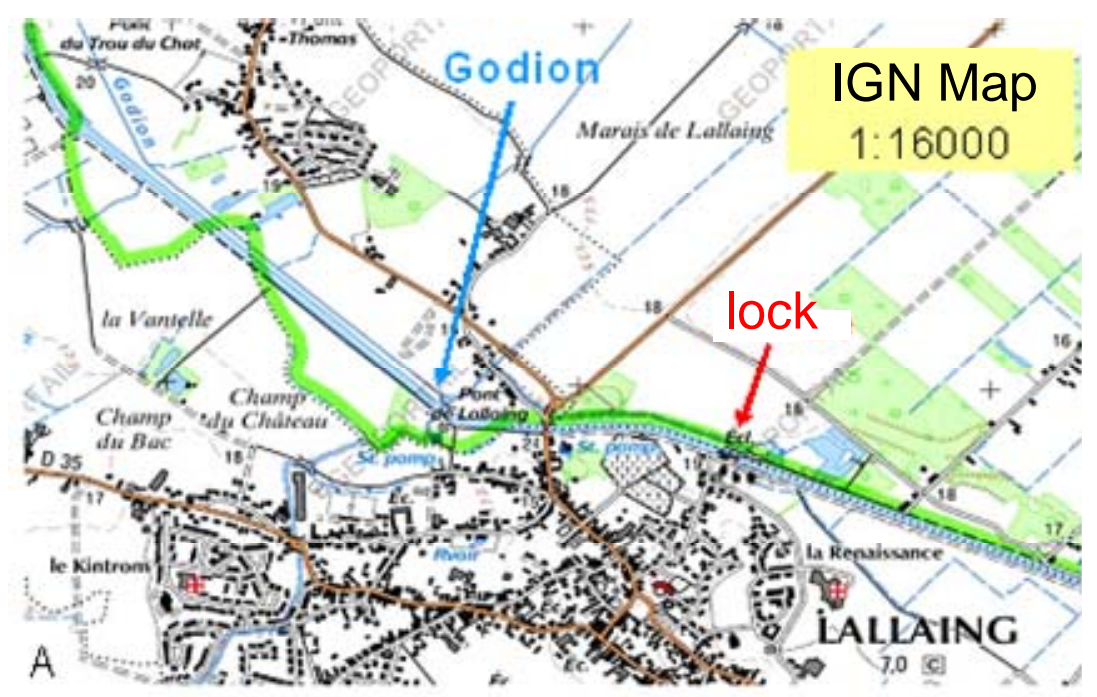

Figure 1. Dredging area map. 


\subsection{Plant material}

A. halleri, a perennial plant, develops populations on metal contaminated soils and noncontaminated soils in Europe (BERT et al., 2002). Seeds of metallicolous plant were collected in a smelter-impacted site (Auby, Fr, $\mathrm{pH}=6.80$ ) and non-metallicolous plant in an uncontaminated site (Hautes Fagnes, $\mathrm{Be}, \mathrm{pH}=6.94$ ).

\subsection{Pot experiment}

A. halleri seeds were germinated on compost for 4 weeks. Seedlings were transferred to the sediment pots after roots had been washed carefully with deionised water. Seedlings were grown in $4 \mathrm{~L}$ pots containing $2.8 \mathrm{~kg}$ of sieved $(<5 \mathrm{~mm})$ sediment. Non vegetated pots were used as control. Each pot contained one seedling and was triplicated. Soil and sediment moistures were maintained at $80 \%$ field water capacity by regular addition of deionised water. Plants were grown for five months in controlled conditions (12h photo period, $20 / 16{ }^{\circ} \mathrm{C}$ day/night temperature, $80 \%$ relative humidity).

Before the start of the experiment, total metal concentrations, total carbon and $\mathrm{pH}$ in the sediment were measured. Health status and plant growth were regularly monitored by counting new leaves and measuring the size of the rosette. Once a month, leachates were collected at the bottom of the pots after the substrate (cultivated and noncultivated) had been sprinkled with $1 \mathrm{~L}$ of deionised water. Besides, on monthly sacrificed pots, three plants were harvested to analyze their aboveground parts. Total Cd and $\mathrm{Zn}$ concentrations were measured in sediment, leachates and plants.

\subsection{Chemical analyses}

Sediment samples were oven-dried at $50^{\circ} \mathrm{C}$, ground in an agate mortar and sieved $(<100$ $\mu \mathrm{m})$. Aliquots of $0.5 \mathrm{~g}$ of sediment was digested in closed vessels using a mixture of $\mathrm{HCl}(6 \mathrm{ml}), \mathrm{HNO}_{3}(2 \mathrm{ml})$ and $\mathrm{H}_{2} \mathrm{O}(1 \mathrm{ml})$ heated in a microwave oven. The filtered extract was adjusted to $100 \mathrm{ml}$ with Milli-Q ${ }^{\circledR}$ water, and stored at $4^{\circ} \mathrm{C}$ before analysis. Leachates were filtered $(0.45 \mu \mathrm{m})$, then aliquots of $10 \mathrm{~mL}$ were acidified with $\mathrm{HNO}_{3}$ (Suprapur ${ }^{\circledR}$ ) and stored at $4^{\circ} \mathrm{C}$ before analysis.

At harvest, shoots and leaves were washed with deionised water. Leaves were ovendried at $50^{\circ} \mathrm{C}$ for 3 days, then leaf biomass was weighed and finally ground and homogenised to prepare one aliquot per pot. Total concentrations of $\mathrm{Cd}$ and $\mathrm{Zn}$ in plant tissues were determined after digestion of $1 \mathrm{~g}$ dry matter in $10 \mathrm{ml}$ of $\mathrm{HNO}_{3}$ and $3 \mathrm{ml}$ of $\mathrm{H}_{2} \mathrm{O}$, in a microwave oven. Solutions were filtered, adjusted to $100 \mathrm{ml}$ with Milli-Q ${ }^{\circledR}$ water and stored at $4^{\circ} \mathrm{C}$ before analysis.

Metal concentrations in sediment, leachates and plant aboveground parts of A. halleri of two origins were determined by ICP-AES (inductively coupled plasma - atomic emission spectroscopy). Quality control for sediment and plant samples was based on the use of certified standard samples (sediment: NWRI TH-2; spinach leaves: SRM 1570a) and internal control samples. 
Is phytoextraction a suitable green treatment for metal contaminated sediments?: 4.5

\section{$2.5 \underline{\text { Statistics }}$}

Statistic analysis was performed using one-way ANOVA followed by post hoc comparison using Tukey's test for comparison of individual means, using the statistical program SPSS 15.0, 2007 version.

\subsection{Physical methods}

Firstly, Cd speciation was studied in freshly dredged sediment. The sediment was freeze-dried, ground and pressed as pellets for EXAFS measurements. Cd K-edge EXAFS spectra of powder samples were recorded on the beamline FAME (ESRF, Grenoble, France) at $15 \mathrm{~K}$ using a He cryostat. Secondly, Cd speciation was studied in the sediment just before the phytoextraction treatment, i.e. just before plant transfer. The sediment was prepared as describe above. One part of the freeze-dried sediment was embedded in epoxy resin, cut to $30 \mu \mathrm{m}$-thick thin sections, micro-polished and mounted on glass slides, and the other part was pressed as pellets. Thin sections were examined by environmental SEM-EDS and by $\mu$ XRF, Cd L LII-edge $\mu$ XANES and S Kedge $\mu$ XANES spectroscopy on the beamline LUCIA (SLS, Villigen, Switzerland) with a spot size of $3 x 3 \mu \mathrm{m}$. Sediment pellets were examined by Cd LIII-edge $\mu$ XANES and $S$ K-edge $\mu$ XANES spectroscopy too. Sample spectra were compared to model compound spectra, including Cd minerals, Cd-sorbed minerals and Cd-complexed organic compounds, fitted by linear combinations of these reference spectra and shell simulated using IFEFFIT suite of programs (RAVEL \& NEWVILLE, 2005).

\section{Results and discussion}

\subsection{Sediment characterization}

The sediment under study presented a neutral $\mathrm{pH}(7.48 \pm 0.01)$ and was relatively rich in organic carbon $(11.65 \pm 0.05 \%)$. After seven months, its water content was still of about 20\%. Cd and Zn contents were around 140 and $4000 \mathrm{DW} \mathrm{mg} \mathrm{kg}^{-1}$, respectively (table 1), i.e., clearly higher than the geochemical background (around 0.5 and $75 \mathrm{mg} \mathrm{kg}^{-1}$ respectively, data from Agence de l'Eau Artois-Picardie). Moreover, fine particles represented about $70 \%$ of total weight sediment and Cd was mainly associated with these fine particles (HUGUET et al., 2007b).

Table 1. Sediment metal concentrations $\left[\mathrm{mg} \mathrm{kg}^{-1}\right]$, average on ten samples.

\begin{tabular}{llllll}
\hline & As & $\boldsymbol{C d}$ & $\boldsymbol{C u}$ & $\boldsymbol{P b}$ & $\mathbf{Z n}$ \\
\hline Metal concentrations $\left[\mathrm{mg} \mathrm{kg}^{-1}\right]$ & 57 & 141 & 233 & 600 & 4074 \\
Standard deviations & 4 & 24 & 9 & 2 & 280 \\
\hline
\end{tabular}


The speciation of $\mathrm{Cd}$ in freshly dredged sediment was examined by EXAFS spectroscopy. Linear combination fits of the sediment spectrum showed that greenockite was the closest reference, but did not match correctly the sediment spectrum. Adding a second component did not improve the fit, suggesting that our database of Cd reference compounds did not contain the species present in the sediment.
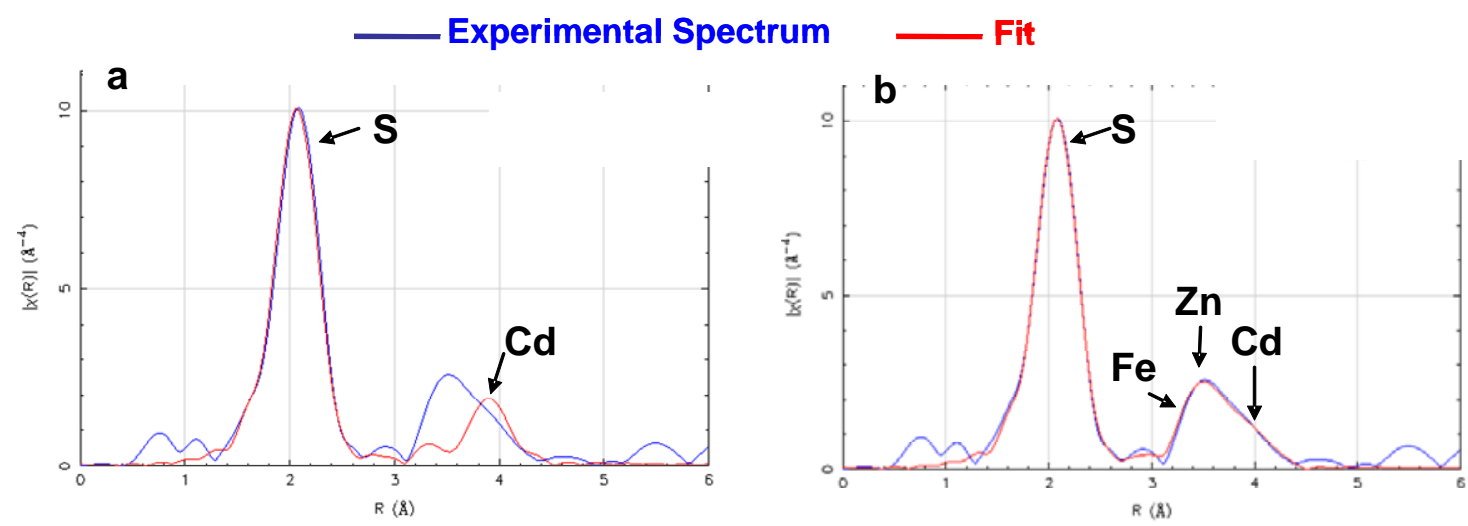

Figure 2. (a) Fourier transforms of Cd K-edge EXAFS spectrum (blue line) for the freshly dredged sediment, and of FEFF simulation with a $S$ first shell and a Cd second shell (red line). (b) Fourier transform of same spectrum simulated with a S first shell and $a \mathrm{Cd}, \mathrm{Zn}$, Fe second shell.

The sediment spectrum was then treated by shell simulations. The first shell was simulated with $3.9 \mathrm{~S}$ at $2.52 \AA$. The second shell was not correctly simulated with Cd only (Fig. 2a), but by a mixture of Cd and Zn (not shown) or of Zn, Cd and Fe (7.2 Zn, 2.6 Cd and $1.4 \mathrm{Fe}$ at $3.88 \AA, 4.18 \AA$ and $3.69 \AA$, respectively, Fig. 2b). This suggested that $\mathrm{Cd}$ occurred as a mixed $\mathrm{Cd}, \mathrm{Zn}, \mathrm{Fe}$-sulphide.

Micro-scale investigations were achieved to precise $\mathrm{Cd}$ speciation and to identify possible minor forms of $\mathrm{Cd}$ in sediment before culture, i.e. just before plant transfer. SEM-EDS enabled the localization of Cd-rich regions in sediment thin sections and provided geochemical associations between the elements. The grains on the backscattered electron image shown in Fig. 3a contained associations of Cd, Fe, Zn and $S$ (Fig. 3c-f), which was consistent with the EXAFS results obtained on this same sediment (not shown). These grains were found to be representative of Cd enriched zones in the sample.

The comparison of $\mu$ XANES spectra recorded on Cd-rich regions with reference spectra supported the hypothesis of metallic sulphide as major Cd species (Fig. 4). Sulphur Kedge XANES spectroscopy was also used to investigate the oxidation state of sulphur, which ranges from -II to +VI. Sulphur was found to be present in reduced form in the metals- and S- rich grains, and as a mixture of reduced and oxidized species in other regions, (Fig. 4b). 
To sum up, Cd was present as a mixed Cd,Zn,Fe-sulphide in the sediment. This result was consistent with the identification of pyrite (FeS) and sphalerite (ZnS) in similar sediments (ISAURE et al., 2002; PANFILI et al., 2005). CdS was also identified in marine sediments (O’DAY et al., 1998).

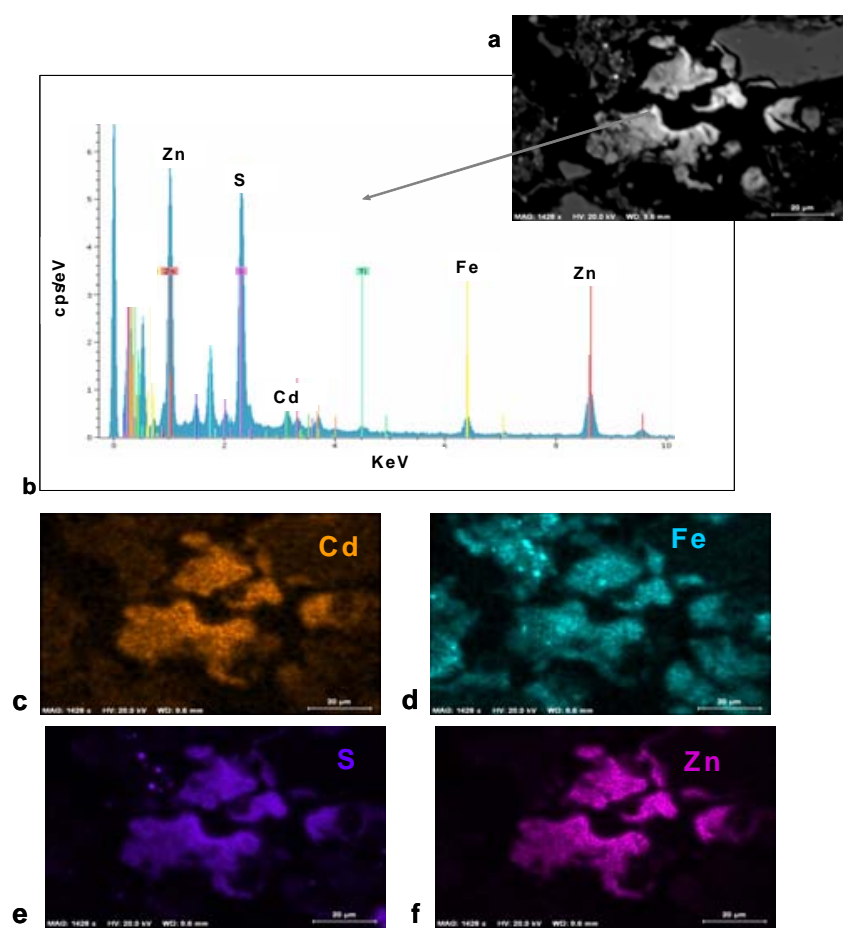

Figure 3. (a) Backscattered electron SEM image. (b) EDS spectrum of a Cd-rich spot of the sediment thin section (sediment state: just before plant transfer). (c-f) Elemental maps for $\mathrm{Cd}, \mathrm{Fe}$, S and $\mathrm{Zn}$ of this region.

The speciation of $\mathrm{Cd}$ in the sediment just before plant transfer was similar to the one found in the freshly dredged sediment, as studied by Cd LIII-edge XANES spectroscopy. Thus, there was no impact of the sediment preparation (dry and homogenization). The sediment after 5 -month culture with A. halleri is currently being studied. PANFILI et al. (2005) showed that plants favour the oxidation of $\mathrm{ZnS}$ and the formation of Zn-phosphate, so a similar phenomenon might take place for $\mathrm{Cd}$. Open questions include the stability of the $\mathrm{Cd}, \mathrm{Zn}, \mathrm{Fe}$-sulphide and the nature of the distribution of possible secondary species. These processes might change the bioavailability of $\mathrm{Cd}$, and thus the efficiency of the phytoextraction.

\subsection{Plant growth parameters}

Each month, health of plants, rosette sizes and biomass were measured and three different individuals were harvested. 
At the beginning of the experiment, when plants were transferred on sediment, plants of both origins presented similar biomasses, i.e. $3.0 \pm 1.1 \mathrm{~g}$ and $3.2 \pm 1.7 \mathrm{~g}$ (average for $\mathrm{n}=3 \pm \mathrm{SD}$ (standard deviation), Fig.5a). For the metallicolous origin, aboveground part biomass was increased after one month, up to $15.3 \pm 3.1 \mathrm{~g}$ (Fig. $5 \mathrm{a}$ ). The increase of the biomass production for plants of non-metallicolous origin $(7.4 \pm 4.3 \mathrm{~g}$ at one month, Fig. 5a) was not significant. Standard deviations were important; for instance, after one month of growth, one plant produced $3.4 \mathrm{~g}$ of biomass whereas another plant produced $11.9 \mathrm{~g}$ of biomass. Regardless of the origin of the plants, plants looked healthy with no visual symptoms of toxicity.
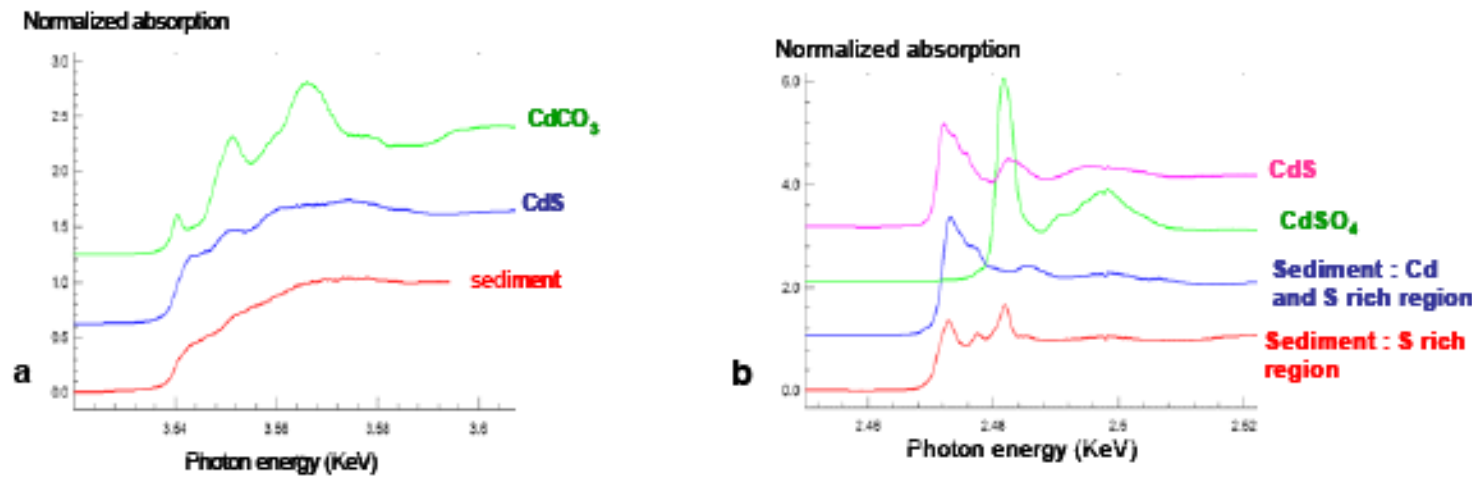

Figure 4. (a) Cd $L_{I I I}$-edge $\mu X A N E S$ spectra of a Cd-rich region of sediment and reference compounds and (b) $S$ K-edge $\mu X A N E S$ spectra recorded on two sediment samples (one Cd and $S$ rich region and one $S$ rich region).
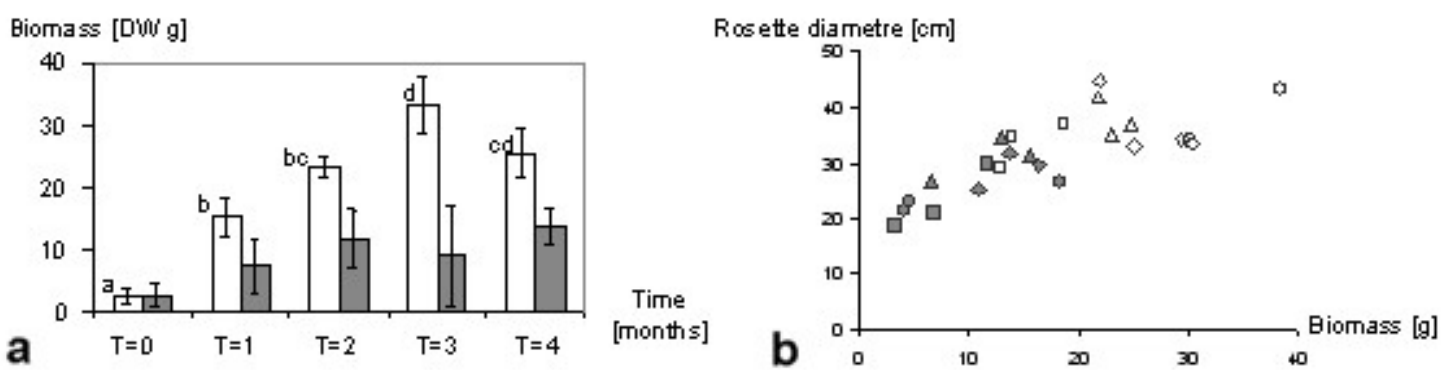

Figure 5. (a) Average values of biomass $(n=3 \pm S D)$ measured in aboveground parts of A. halleri from a metallicolous (white) and non-metallicolous origins (dark grey) before plant transfer on sediment (TO) and during the first four months of monitoring ( $\mathrm{T} 1=1$, $\mathrm{T} 2=2, \mathrm{~T} 3=3$ and $\mathrm{T} 4=4$ months). A different letter means a significant difference at 5\% (one-way ANOVA followed by a Tukey test). The one-way ANOVA is not significant for non metallicolous plants. (b) Relationship between plant biomass and rosette diameter for metallicolous (white) and non-metallicolous plants (dark grey) at each time of monitoring (rectangles represent T1, triangles T2, circles T3 and diamond T4). 
From T1 to T4, plants from metallicolous origin produced more biomass than plants from non-metallicolous origin (Fig. 5a). The maximum difference in biomass was observed the third month of the experiment where plants of metallicolous origin reached $33.1 \pm 4.6 \mathrm{~g}$ whereas plants of non-metallicolous origin reached the average value of $9.1 \pm 8.0 \mathrm{~g}$. Here again standard deviations for non-metallicolous origin were important. No significant increase in biomass was observed for plants from non-metallicolous origin between the first and fourth month (Fig. 5a; $>>0.05$ ). This difference between the two origins of $A$. halleri was highlighted by the correlation diagram between plant biomass and rosette diameter (Fig. 5b). Indeed, the two origins appeared clearly in two distinct groups, with higher biomass and rosette diameter for metallicolous plants (13 to $38.5 \mathrm{~g}$ and 29.5 to $44.5 \mathrm{~cm}$ ) than for non-metallicolous plants (3.4 to $18.4 \mathrm{~g}$ and 18.5 to $34.5 \mathrm{~cm})$.

From biomass results, $A$. halleri from metallicolous origin appeared more suitable for phytoextraction than $A$. halleri from non-metallicolous origin.

\subsection{Evolution of Cd and Zn concentrations in aboveground parts of A. halleri}

Cd concentrations were measured each month on three harvested plants (12 values for each population, Fig. 6a). For each origin tested separately, no significant difference was observed ( $>0.05)$ (Fig. 6a). Maximum average $\mathrm{Cd}$ concentrations were $145 \pm 90 \mathrm{mg} \mathrm{kg}^{-1}(\mathrm{n}=3 \pm \mathrm{SD})$ and $185 \pm 18 \mathrm{mg} \mathrm{kg}^{-1}$ for, respectively, metallicolous origin at $\mathrm{T} 4$ and non-metallicolous origin at T1 (Fig. 6a). At T4, the Cd concentration non metallicolous plants was $129 \pm 40 \mathrm{mg} \mathrm{kg}^{-1}(\mathrm{n}=3 \pm \mathrm{SD})$. There was not significant difference between origins ( $p>0.05$ ). Standard deviations were important, suggesting a high interindividual variability in $\mathrm{Cd}$ accumulation. As a comparison, this species accumulated up to $6000 \mathrm{mg} \mathrm{kg}^{-1}$ after 14 weeks growth in hydroponics containing Cd (KUPPER et al., 2000).

To sum up, Cd concentrations did not increase significantly with time regardless of the origin of A. halleri. Plants seemed to have reached a maximum value after one month only. In order to explain this "plateau response", two hypotheses can be proposed. Cd accumulation could be limited by Cd phytoavailability (CHRISTENSEN \& TJELL, 1984; CHANEY \& RYAN, 1993; DAHMANI-MULLER et al., 1999; McGRATH et al., 2006) or the plant itself could limit the entry of the metal to prevent toxicity (McBRIDE, 1995; GUERINOT \& EIDE, 1999; BERT et al., 2002). 
Cd concentration [mg. $\left.\mathrm{kg}^{-1}\right]$

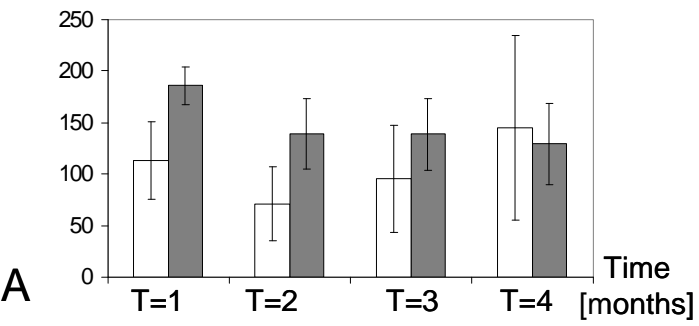

Zn concentration $\left[\mathrm{mg} \cdot \mathrm{kg}^{-1}\right]$

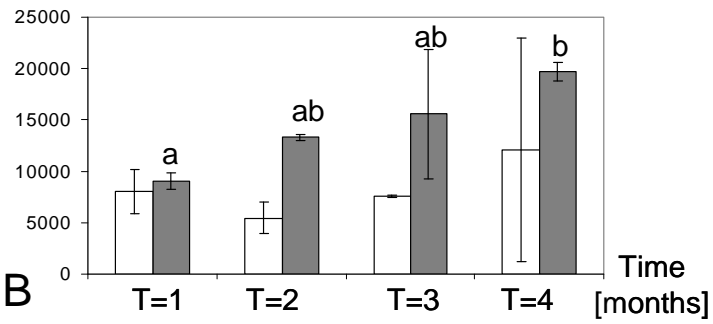

Figure 6. Average of Cd (A) and $\mathrm{Zn}(\mathrm{B})$ concentrations $\left[\mathrm{mg} \mathrm{kg}^{-1}\right]$ measured in aboveground parts of A. halleri from metallicolous (white) and non-metallicolous (dark grey) origins during the first four months of monitoring (averages and standard deviations over 3 samples). A letter means a significant difference at 5\% (one-way ANOVA followed by a Tukey test). The one-way ANOVA is not significant for metallicolous plants.

For $\mathrm{Zn}$ accumulation, A. halleri from metallicolous origin showed the same behaviour than for Cd accumulation. For metallicolous plants, no significant difference was observed at the various times ( $>0.05$ ) (Fig. 6b). Again, standard deviations were very high, suggesting a high individual variability of plants, particularly at T4. Indeed, the three replicate plants had accumulated 24577, 4578 and $7091 \mathrm{mg} \mathrm{kg}^{-1}$ (Fig. 6b). On the contrary, Zn concentration in aboveground parts of $A$. halleri from non-metallicolous origin increased significantly between the first and the fourth month of culture. At T2 and T3, plants from non-metallicolous origin accumulated more $\mathrm{Zn}$ than plants from metallicolous origin (Fig. 6b), but interindividual variability was important at T3 (22835, 12281 and $11578 \mathrm{mg} \mathrm{kg}^{-1}$ ). To conclude on Zn accumulation, A. halleri from non-metallicolous origin showed a different behaviour than for $\mathrm{Cd}$ accumulation. This result was consistent with that of BERT et al. (2000).

\subsection{Phytoextration yield of Arabidopsis halleri}

From results of biomass, $\mathrm{Cd}$ and $\mathrm{Zn}$ accumulation in aerial parts and in leachates, the amount of $\mathrm{Cd}$ present in the sediment and extracted by A. halleri was calculated. Put under optimal conditions in the growth chamber, for both origins, after 1-month growth, plants extracted around $1.5 \mathrm{mg} \mathrm{Cd} \operatorname{pot}^{-1}$. On the other hand, after 4-month growth, plants from metallicolous origin extracted about $3.7 \pm 0.3 \mathrm{mg} \mathrm{Cd}$ pot $^{-1}$ whereas plants from non-metallicolous extracted $1.8 \pm 0.1 \mathrm{mg} \mathrm{Cd} \mathrm{pot}^{-1}$. For plants from metallicolous origin, the extraction yield seemed to increase with time (table 2). Indeed, after one month of growth, the plant extracted $0.41 \pm 0.1 \%$ of the $\mathrm{Cd}$ present in the sediment pot, and $0.98 \pm 0.7 \%$ after four months (table 2 ). The maximum Cd extraction was $1.8 \%$ and was obtained after four months. By contrast, Cd extraction by A. halleri from nonmetallicolous origin was significantly lower (maximum of $0.7 \%$, obtained after three 
Is phytoextraction a suitable green treatment for metal contaminated sediments?: 4.11

and four months). The maximum $\mathrm{Zn}$ extraction yield was $6.3 \%$ after three months for the metallicolous origin, and $2.9 \%$ after four months of growth for the other origin.

Less than $0.05 \%$ of $\mathrm{Cd}$ present in the sediment pot at the beginning of the experiment was lost in leachates. In spite of the Cd extraction by A. halleri and Cd lost in leachates, the Cd majority was still in the sediment (table 2). The same trends were observed for Zn (table 2).

Table 2. Material balance of $\mathrm{Cd}$, in percent, between plant, leachates and sediment compartments, after one and four months of culture by A. halleri from a metallicolous and a non-metallicolous origin.

\begin{tabular}{lccccccc}
\hline \multirow{2}{*}{$\begin{array}{l}\text { A. halleri origin } \\
\end{array}$} & \multicolumn{2}{c}{ culture time } & \multicolumn{2}{c}{ Extracted by plant [\%] } & \multicolumn{2}{c}{ in leachates [\%] } & \multicolumn{2}{c}{ still in sediment [\%] } \\
[months] & Cd & Zn & Cd & Zn & Cd & Zn \\
\hline metallicolous & \multirow{2}{*}{1} & $0,41 \pm 0,10$ & $1.03 \pm 0.2$ & $0,025 \pm 0,010$ & $0.05 \pm 0.02$ & $88,0 \pm 5,0$ & $93.34 \pm 5.48$ \\
non metallicolous & & $0,34 \pm 0,17$ & $0.63 \pm 0.4$ & $0,025 \pm 0,012$ & $0.04 \pm 0.02$ & $90,1 \pm 2,1$ & $100.45 \pm 1.90$ \\
\hline metallicolous & \multirow{2}{*}{4} & $0,98 \pm 0,74$ & $3.08 \pm 3.0$ & $0,044 \pm 0,020$ & $0.05 \pm 0.03$ & $96,7 \pm 2,9$ & $92.33 \pm 1.49$ \\
non metallicolous & & $0,46 \pm 0,21$ & $2.52 \pm 0.6$ & $0,019 \pm 0,010$ & $0.02 \pm 0.01$ & $91,6 \pm 2,2$ & $91.06 \pm 3.38$ \\
\hline
\end{tabular}

\section{Conclusion and perspectives}

Concerning the assessment of the potential of A. halleri for Cd phytoextraction in a contaminated sediment, several results can be highlighted. Plants could adapt and grow on this matrix, and few Cd was leached. Moreover, plants accumulated $100 \mathrm{mg} \mathrm{Cd} \mathrm{kg}^{-1}$ DW in their aboveground parts from the first month of culture. For phytoremediation, the ideal plant should possess multiple characteristics including fast growing, high biomass, deep roots, ease to harvest and high metal tolerance and accumulation in their aerial and harvestable parts (CLEMENS et al., 2002). KLANG-WESTIN \& ERIKSSON (2003) postulated that biomass production is the crucial parameter for phytoextraction. The efficiency of the phytoextraction also depends on the composition of the substrate and speciation of metals (BARCELO \& POSCHENRIEDER, 2003). Before culture, Cd was present as mixed $\mathrm{Zn}, \mathrm{Cd}$ and Fe sulphide. Based on previous work on $\mathrm{Zn}$ in a similar sediment (PANFILI et al., 2005), one can expect the oxidation of sulphides and the redistribution of metals in new phases. A precise characterization of substrate and Cd chemical forms and phytoavailability after culture is needed to test these hypotheses. Such investigations are currently under way.

\section{References}

ALARY C. (2001). Technical report Douai - Fr., CNRSSP: 72 p.

BAKER A.J.M., BROOKS R.R. (1989). Terrestrial higher plants which hyperaccumulate metallic elements-A review of their distribution, ecology and phytochemistry. Biorecovery 1, pp 81-126.

BARCELO J., POSCHENRIEDER C. (2003). Phytoremediation: principles and perspectives. Contribut. Sci. 2, pp 333-344. 
BECHER M., TALKE I.N., KRALL L., KRAMER U. (2004). Cross-species microarray transcript profiling reveals high constitutive expression of metal homeostasis genes in shoots of the zinc hyperaccumulator Arabidopsis halleri. Plant Journal 37 (2), pp 251-268.

BERT V., MACNAIR M.R., DE LAGUERIE P., SAUMITOU LAPRADE P., PETIT D. (2000). Zinc tolerance and accumulation in metallicolous populations of Arabidopsis halleri (Brassicaceae). New Phytologist. 146, pp 225-233. doi:10.1046/j.14698137.2000.00634.x

BERT V., BONNIN I., SAUMITOU LAPRADE P., DE LAGUERIE P., PETIT D. (2002). Do Arabidopsis halleri from nonmetallicolous populations accumulate zinc and cadmium more effectively than those from metallicolous populations? New Phytologist 155 (1), pp 47-57. doi:10.1046/j.1469-8137.2002.00432.x

BERT V., MEERTS P., SAUMITOU LAPRADE P., SALIS P., GRUBER W., VERBTUGGEN N. (2003). Genetic basis of Cd tolerance and hyperaccumulation in Arabidopsis halleri. Plant and Soil 249 (1), pp 9-18. doi:10.1023/A:1022580325301

CHANEY R.L., RYAN J.A. (1993). Heavy metals and toxic organic pollutants in MSW-composts: Research results on phytoavailability, bioavailability, fate, etc. pp 451-506. In Keener (ed) Science and Engineering of Composting: Design, Environmental, Microbiological and Utilization Aspects. Renaissance Publ., Worthington, $\mathrm{OH}$.

CHO M., CHARDONNENS A.N., DIETZ K.J. (2003). Differential heavy metal tolerance of Arabidopsis halleri and Arabidopsis thaliana: a leaf slice test. New Phytologist 158 (2), pp 287-293. doi:10.1046/j.1469-8137.2003.00746.x

CHRISTENSEN T.H., TJELL J.C. (1984). Leaching from land disposed municipal compost: 4. Heavy metals. Waste Management and Research, 2, pp 347-357

CLEMENS S., PALMGREN M.G., KRAMER U. (2002). A long way ahead: understanding and engineering plant metal accumulation. Trends Plant Science, 7(7), pp 309-315. doi:10.1016/\$1360-1385(02)02295-1

COREY R. B., KING L.D., LUE-HING C., FANNING D.S., STREET J.J., WALKER J.M. (1987). Land Application of Sludge: Food Chain Implications, (Eds Page, A. L., Logan, T. G., and Ryan, J. A. A.L. Page, Lewis Publishers, Inc., Chelsea, Michigan, pp 25-51.

CUNNINGHAM S.D., BERTHI W.R., HUANG J.W. (1995). Phytoremediation of contaminated soils. Tends in Biotechnology 13, pp 393-397. doi:10.1016/S0167-7799(00)88987-8

DAHMANI-MULLER H., VAN OORT B., GELIE B. BALABANE M. (1999). Strategies of heavy metal uptake by three plant species growing near a metal smelter. Environmental Pollution. 109, pp 1-8. 
Is phytoextraction a suitable green treatment for metal contaminated sediments?: 4.13

GIRONDELOT B., BERT V., MARSEILLE F., LABOUDIGUE A. (2003). Restoration of a metal polluted dredged sediment deposit. A Phytoremediation inventory, COST Action 837 View. Ed: T. Vanek and JP Schwitzguébel, 68 p.

GUERINOT M.L., EIDE D. (1999). Zeroing in on zinc uptake in yeast and plants. Current Opinion in Plant Biology 2, pp 244-249. doi:10.1016/S1369-5266(99)80042-9

HAE-NAM HYUN A.C., CHANG D.R., PARKER, PAGE A. (1998). Cadmium solubility in sludge-treated soil: effects of soil organic carbon. Journal of Environmental Quality 27, pp 329-334. doi:10.2134/jeq1998.272329x

HUGUET S., LACHEREZ S., LABOUDIGUE A., SARRET G., BERT V. (2007a). Phytoextraction and hyperaccumularting plant : is it possible? Colloque WG4 COST action 859, Vilnius, Lituanie.

HUGUET S., BERT V., LABOUDIGUE A., ISAURE M.P., SARRET G. (2007b). Cd localization and speciation in a contaminated sediment and in the $\mathrm{Zn}, \mathrm{Cd}$ hyperaccumulating plant Arabidopsis halleri. 9th ICOBTE, $330 \mathrm{p}$.

ISAURE, M.P., LABOUDIGUE A., MANCEAU A., SARRET G., TIFFEAU C., TROCELLIER P., LAMBLE G., HAZEMANN J. L., CHATEIGNER D. (2002). Quantitative Zn speciation in a contaminated dredged sediment by mu-PIXE, mu-SXRF, EXAFS spectroscopy and principal component analysis. Geochimica Cosmochimica Acta 66(9), pp 1549-1567. doi:10.1016/S0016-7037(01)00875-4

JING J., LOGAN T. (1992). Effects of sewage sludge cadmium concentration on chemical extractability and plant uptake. Journal of Environmental Quality 21, pp 73-81. doi:10.2134/jeq1992.21173x

KLANG-WESTIN E., ERIKSSON J. (2003). Potential of Salix as phytoextractor for Cd on moderately contaminated soils. Plant and Soil, 249(1), pp 127-137. doi:10.1023/A:1022585404481

KUPPER H., LOMBI E., ZHAO F.J., McGRATH S.P. (2000). Cellular compartmentation of cadmium and zinc in relation to other elements in the hyperaccumulator Arabidopsis halleri. Planta 212, pp 75-84. doi:10.1007/s004250000366

LOMBI E., ZHAO F.J.,. DUHMAN S.J., McGRATH S.P. (2000). Cadmium accumulation in populations of Thlaspi caerulescens and Thlaspi goesingense. New Phytologist 145, pp 53-60. doi:10.1046/j.1469-8137.2000.00560.x

McBRIDE M.B. (1995). Toxic Metal Accumulation from Agricultural Use of Sludge: Are USEPA Regulations Protective? Journal Environmental Quality 24, pp 5-18. doi:10.2134/jeq1995.2415

McGRATH S.P., LOMBI E., GRAY C.W., CAILLE N., DUNHAM S.J., ZHAO F.J. (2006). Field evaluation of $\mathrm{Cd}$ and $\mathrm{Zn}$ phytoextraction potential by the hyperaccumulators Thlaspi caerulescens and Arabidopsis halleri. Environmental Pollution, 2006. 141(1), pp 115-125. doi:10.1016/j.envpol.2005.08.022

O'DAY, P., CARROL S.A., WAYCHUNAS G.A. (1998). Rock-Water interactions controlling zinc, cadmium, and lead concentrations in surface waters and sediments, 
US tri-state mining district. 1. Molecular identification using X-ray absorption spectroscopy. Environmental Science and Technology 32, pp 943-955. doi:10.1021/es970453c

PANFILI F., MANCEAU A., SARRET G., SPADINI L., KIRPICHTCHIKOVA T., BERT V., LABOUDIGUE A., MARCUS M., AHAMDACH N., LIBERT M. (2005). The effect of phytostabilization on Zn speciation in a dredged contaminated sediment using scanning electron microscopy, X-ray fluorescence, EXAFS spectroscopy and principal components analysis. Geochimica Cosmochimica Acta 69, pp 2265-2284. doi:10.1016/j.gca.2004.10.017

RASKIN I., ENSLEY B. (2000). Phytoremediation of Toxic Metals. Wiley.

SARRET G., SAUMITOU LAPRADE P., BERT V., PROUX O., HAZEMANN J. L., TRAVERSE A., MARCUS M., MANCEAU A. (2002). Forms of zinc accumulated in the hyperaccumulator Arabidopsis halleri. Plant Physiology 130, pp 1815-1826. doi:10.1104/pp.007799

RAVEL B., NEWVILLE M. (2005). ATHENA and ARTEMIS: Interactive graphical data analysis using IFEFFIT. J. Synchr. Rad. 12, pp 537-541. doi:10.1107/S0909049505012719 SEUNTJENS, P., MALLAANTS, D., SIMUNEK, J., PATYN, J., JACQUES D. (2002). Sensitivity analysis of physical and chemical properties affecting field-scale cadmium transport in a heterogeneous soil profile. Journal of Hydrology 264 (1-4), pp 185-200. doi:10.1016/S0022-1694(02)00071-9

THIRY M., HUET-TAILLANTER S., SCHMITT J.M. (2002). La friche industrielle de Mortagne-du-Nord (59) -I- Prospection du site, composition des scories, hydrochimie, hydrologie et estimation des flux. Bulletin Société Géologique de France 173/4, pp 369381. doi:10.2113/173.4.369

WEBER M., HARADA E., VESS C., VON ROEPENACK LAHAYE E., CLEMENS S. (2004). Comparative microarray analysis of Arabidopsis thaliana and Arabidopsis halleri roots identifies nicotianamine synthase, a ZIP transporter and other genes as potential metal hyperaccumulation factors. Plant Journal 37 (2), pp 269-281.

ZHAO F., LOMBI E., BREEDON T., McGRATH S.P. (2000). Zinc hyperaccumulation and cellular distribution in Arabidopsis halleri. Plant, Cell and Environment 23: pp 507-514. doi:10.1046/j.1365-3040.2000.00569.x

ZHAO F., JIANG R.F., DUNHAM S.J., McGRATH S.P. (2006). Cadmium uptake, translocation and tolerance in the hyperaccumulator Arabidopsis halleri. New Phytologist, 172, pp 646-654. doi:10.1111/j.1469-8137.2006.01867.x 